\title{
UJI KUALITATIF KANDUNGAN BORAKS PADA KULIT PANGSIT YANG BEREDAR DI BEBERAPA PASAR KOTA MAKASSAR
}

\author{
Yusnita Usman \\ STIKES Nani Hasanuddin Makassar
}

\begin{abstract}
ABSTRAK
Boraks memiliki dampak negatif terhadap kesehatan karena memiliki efek toksik yang dapat membahayakan sistem metabolisme kesehatan manusia seperti iritasi saluran pernafasan, kulit, mata, ginjal, jantung, dan system reproduksi. Penelitian ini bertujuan untuk melakukan uji senyawa boraks secara kualitatif pada kulit pangsit di pasar A, B, dan C di Kota Makassar. Penelitian inimenggunakan analisis kualitatif dengan menggunakan 2 metode yakni uji nyala api dan uji warna pada paper test kit sederhana dengan kunyit. Penelitian dengan menggunakan metode uji nyala api dilakukan dengan menambahkan asam sulfat dan metanol pada sampel yang sebelumnya telah dipanaskan di oven dengan suhu $120^{\circ} \mathrm{C}$ selama 6 jam dan dipijarkan dengan Bunsen kemudian dibakar dan diamati perubahan warna api. Pengujian dengan paper test kit sederhana dilakukan menggunakan air kunyit pada paper test kemudian dikeringkan di bawah sinar matahari. Pengujian dengan uji warna kunyit dilakukan dengan membuat ekstrak dari sampel kemudian di teteskan ke paper test kit dan diamati perubahan warnanya. Hasil penelitian menunjukkan bahwa sampel A, B, dan C dengan menggunakan metode uji nyala api dan dengan uji paper test kit dinyatakan tidak mengandung boraks.
\end{abstract}

Kata Kunci :Uji Kualitatif, Boraks, Kulit Pangsit

\section{PENDAHULUAN}

Makanan merupakan kebutuhan pokok seharihari yang berperan penting untuk kelangsungan hidup manusia. Aktivitas manusia akan mengalami hambatan jika makanan yang dikonsumsi tidak cukup dalam jumlah dan mutunya. Makanan dapat diperoleh dari tumbuhan (nabati) dan hewan (hewani), dengan tujuan sebagai zat gizi bagi tubuh yang dibutuhkan untuk mempertahankan hidup. Makanan juga mempunyai peranan yang penting dalam kesehatan, tetapi kesadaran masyarakat terhadap kualitas makanan terabaikan karena beberapa faktor seperti daya beli yang masih rendah, atau pemilihan dari produk makanan itu sendiri yang sering dikaitkan dengan kandungan gizi dalam produk makanan (Falahudin et al., 2016).

Makanan yang aman merupakan faktor yang penting untuk meningkatkan derajat kesehatan. Dalam undang-undang RI No.7 Tahun 1996 tentang pangan, keamanan pangan didefinisikan sebagai kondisi dan upaya yang diperlukan untuk mencegah pangan dari kemungkinan cemaran biologis, kimia, benda-benda lain yang dapat mengganggu, merugikan dan membahayakan kesehatan manusia (Aseptianova et al., 2017).

Kulit pangsit adalah makanan berbentuk lembaran tipis, dipakai sebagai pembungkus daging cincang. Selain direbus dan dikukus, pangsit juga bisa di goreng dengan minyak goreng seperti kerupuk. Kulit pangsit terbuat dari tepung terigu, tepung tapioka, air, garam dan margarin yang dicampur, diuleni hingga kalis kemudian digiling hingga mencapai ketebalan tertentu dan dibentuk sesuai selera (Fauziyah dan Choirul, 2014).
Bahan pangan keluaran pabrik pada umumnya menggunakan bahan tambahan pangan (food aditives), seperti bahan pengawet yang secara sengaja ditambahkan agar bahan pangan yang dihasilkan dapat dipertahankan kualitasnya dan memiliki umur simpan lebih lama sehingga memperluas jangkauan distribusinya. Tanpa bahan tambahan pangan, khususnya bahan pengawet maka bahan pangan yang tersedia di pasar atau di swalayan akan menjadi kurang menarik, tidak dapat dinikmati secara layak, dan tidak awet. Bahan pengawet yang ditambahkan umumnya sama dengan bahan pengawet pangan yang sebenarnya sudah terdapat dalam bahan pangan, tetapi jumlahnya sangat kecil sehingga kemampuan mengawetkan sangat rendah (Cahyadi, 2009).

Penggunaan Bahan Tambahan Pangan (BTP) dalam penanganan dan pengolahanhampir tidak bisa dihindarkan. Ketakutan masyarakat terhadap penggunaan BTP cukup beralasan karena kurangnya informasi dan lemahnya penegakan hukum jika terjadi masalah. Banyak pihak tidak bertanggung jawab, tidak peduli, tidak tau atau apapun alasannya melakukan praktek penambahan BTP terlarang untuk mendapatkan keuntungan (Kristianto, 2010).

Konsentrasi bahan pengawet yang diizinkan sifatnya adalah penghambatan dan bukannya mematikan organisme-organisme pencemar. Oleh karena itu, populasi mikroba dari bahan pangan yang diawetkan harus dipertahankan seminimum mungkin. Bahan kimia berbahaya yang bukan ditujukan untuk makanan, justru ditambahkan kedalam makanan misalnya boraks akan sangat membahayakan konsumen (Dolot et al., 2016). 
Dampak negatif bagi tubuh yang disebabkan oleh pangan terutama yang mengandung boraks pada dosis antara 10-20 gr per kg berat badan orang dewasa dan 5 gr per kg berat badan anak-anak akan menyebabkan keracunan bahkan kematian. Sedangkan dosis dibawah 10-20 gr per kg berat badan orang dewasa dan kurang dari $5 \mathrm{gr} / \mathrm{kg}$ berat badan anak-anak, jika sering dikonsumsi akan menumpuk/terakumulasi pada jaringan tubuh di otak, hati, lemak dan ginjal yang pada akhirnya dapat memicu terjadinya kanker (Muharrami, 2015).

Boraks telah lama digunakan sebagai pengawet makanan, tetapi sejak 1925 penggunaan boraks untuk makanan tidak diperbolehkan lagi. Pada saat perang dunia ke-2 berlangsung, larangan tersebut dilonggarkan dan boraks kembali diizinkan penggunaannya untuk mengawetkan minyak babi dan margarin. Namun, pada 1959, Food Standard Committee kembali melarang penggunaan boraks karena pengawet tersebut dikategorikan sebagai bahan yang tidak diinginkan karena adanya sifat kumulatif atau dapat menimbulkan efek membahayakan tubuh manusia (Helmawati, 2015).

Boraks adalah zat pengawet yang banyak digunakan dalam industri pembuatan taksidermi, insektarium, dan herbarium, tapi orang cenderung menggunakannya dalam industri rumah tangga sebagai bahan pengawet makanan. Namun banyak masyarakat yang salah penggunaan boraks sebagai pengawet makanan, dan pemutih hanya karena kebutuhan pribadi misalnya penjual makanan untuk makanan lebih awet penjual menambahkan boraks atau industri makanan kemasan tertentu agar produk yang mereka hasilkan tahan lama dipasaran (Falahudin et al ., 2016).

Badan Pengawas Obat dan Makanan (BPOM) menunjukkan bahwa sepanjang tahun 2012, insiden keracunan makanan menduduki posisi paling tinggi yaitu $66,7 \%$ dibandingkan dengan keracunan akibat penyebab lain misalnya obat, komestika, dan lainlain. Salah satu penyebab keracunan makanan adalah adanya cemaran kimia dalam makanan seperti boraks (Misbah et al., 2017).

Dengan latar belakang tersebut, pada penelitian ini akan dilakukan uji kualitatif kandungan boraks pada kulit pangsit yang beredar di beberapa pasar Kota Makassar. Tentunya hasil penelitian ini diharapkan akan memberikan informasi yang bermanfaat mengingat pentingnya ketersediaan produk pangan yang aman dan berkualitas. Selain itu, penelitian ini dilakukan karena belum adanya penelitian yang terpublikasi mengenai uji kandungan boraks pada kulit pangsit yang beredar di beberapa pasar Kota Makassar.

\section{BAHAN DAN METODE}

1. Jenis dan Metode Penelitian

Penelitian ini merupakan penelitian eksperimental dengan menggunakan metode analisis kualitatif kandungan boraks.

2. Lokasi dan Waktu Penelitian

Penelitian dilakukan di Laboratorium Kimia Prodi DIII Farmasi STIKES Nani Hasanuddin pada Juli 2020

3. Populasi dan Sampel

Populasi penelitian adalah seluruh kulit pangsit yang dijual di pasar Kota Makassar. Sedangkan sampel penelitian ini adalah kulit yang diambil dari 3 pasar berbeda di Kota Makassar yaitu Pasar A (Daya), B (BTP) dan C (Terong) yang diambil dengan metode acak.

4. Alat dan Bahan

Alat yang digunakan adalah Beaker glass, bunsen, cawan porselin, cawan petri, korek api, oven, pipet tetes, penjepit, mortar, dan penggerus. Sedangkan bahan yang digunakan adalah Asam sulfat, aquadest, metanol, kertas whatman, kertas saring, paper test kit dan kulit pangsit, dan tissue.

5. Prosedur Kerja

a. Metode uji nyala api

Sampel ditimbang sebanyak 10 gram dan dipotong-potong kecil lalu dipanaskan di oven pada suhu $120^{\circ} \mathrm{C}$ selama 6 jam, kemudian sampel dimasukkan kedalam cawan porselin selanjutnya dipijarkan pada suhu $600^{\circ} \mathrm{C}$ menggunakan Bunsen, sisa pemijaran ditambahkan 1-2 tetes asam sulfat pekat dan 5-6 tetes metanol, kemudian dibakar. Bila timbul nyala api hijau, maka menandakan positif mengandung boraks

b. Uji warna kunyit dengan paper test kit sederhana

Proses pembuatan paper test kit, yaitu (Santi, 2017):

1. Kunyit ditumbuk halus dengan menggunakan mortar, ditambahkan sedikit air

2. Cairan disaring didalam beaker glass

3. Air kunyit di dalam beaker glass sebagian dituangkan pada cawan petri

4. Kertas whatman dicelupkan kedalam cawan Petri dan dibolak balik hingga semua permukaannya rata dengan air kunyit

5. Kemudian kertas whatman ditata diatas papan dan dikeringkan dibawah terik sinar matahari

6. Sebagai acuan dibuat satu pembanding dari kertas whatman yang sudah kering diteteskan dengan larutan boraks Pengujian kandungan boraks dilakukan dengan cara yaitu :

a. Membuat ekstrak dari makanan yang akan diuji kandungan boraksnya 
b. Kemudian ditumbuk dan ditambahkan sedikit air sehingga ekstraknya dapat diambil

c. Kemudian diteteskan ke paper test kit apabila warnanya berubah menjadi coklat maka makanan mengandung boraks.

6. Analisis Data

Data penelitian kemudian dikumpulkan dan dikategorikan berdasarkan lokasi pengambilan sampel dan metode analisis yang digunakan. Uji nyala nilai positif menandakan nyala api berwarna hijau, sedangkan nilai negatif menandakan nyala api berwarna merah. Dan pada uji warna kunyit dengan pembuatan paper test kit sederhana dilihat dari perubahan warna apabila paper test kit berubah warna menjadi coklat maka menandakan positif mengandung boraks.

\section{HASIL PENELITIAN}

Tabel 1. Hasil Uji Nyala Api

\begin{tabular}{|c|c|c|}
\hline Sampel & Hasil Uji & Syarat Uji \\
\cline { 1 - 2 } A & Nyala Api Merah & $\begin{array}{c}\text { *Positif jika nyala api berwarna hijau, } \\
\text { negatif jika nyala api berwarna merah }\end{array}$ \\
\cline { 1 - 2 } B & Nyala Api Merah & \\
\hline C & Nyala Api Merah & \\
\hline
\end{tabular}

*Tabel 1 menunjukkan tidak adanya kandungan boraks pada ketiga sampel pada metode uji nyala

Tabel 2. Hasil Uji Warna pada Paper Test Kit Sederhana dengan Kunyit

\begin{tabular}{|c|c|c|}
\hline Sampel & Hasil Uji & Syarat Uji \\
\hline A & Paper test tetap berwarna kuning & \multirow{3}{*}{$\begin{array}{l}\text { *Positif jika terjadi perubahan warna dari } \\
\text { kuning menjadi coklat, negatif jika tidak } \\
\text { ada perubahan }\end{array}$} \\
\hline B & Paper test tetap berwarna kuning & \\
\hline $\mathrm{C}$ & Paper test tetap berwarna kuning & \\
\hline
\end{tabular}

*Tabel 2 menunjukkan tidak adanya kandungan boraks pada ketiga sampel pada metode paper test kit sederhana

\section{PEMBAHASAN}

Salah satu jenis produk pangan dengan pasta sebagai bahan dasarnya adalah pangsit. Pangsit terbuat dari tepung, air, telur garam, dan kansui serta dicetak dengan ukuran $8-10 \mathrm{~cm}$ di setiap sisinya dan ketebalan $0,5-1 \mathrm{~mm}$. kulit pangsit dapat diisi dengan campuran daging dan sayuran. Secara umum kulit pangsit dapat disajikan dengan cara di rebus atau digoreng. Boraks adalah senyawa berbentuk kristal putih tidak berbau dan stabil pada suhu ruangan (Anugrahati et al., 2017).

Boraks merupakan senyawa kimia dengan nama Natrium tetraborat $\left(\mathrm{NaB}_{4} \mathrm{O}_{7} 10 \mathrm{H}_{2} \mathrm{O}\right)$. Jika larut dalam air akan menjadi hidroksida dan asam borat $\left(\mathrm{H}_{3} \mathrm{Bo}_{3}\right)$. Penggunaan alkali fosfat pada boraks dosis tinggi (lebih dari $5 \%$ atau 5 gram tiap 1 kilogram adonan) dapat menimbulkan rasa sepat atau pahit, teksturnya jelek dan terlalu kenyal seperti karet. Boraks atau asam boraks biasanya digunakan untuk bahan pembuat detergen dan antiseptik. Asam borat juga merupakan bakterisida lemah sehingga dapat digunakan sebagai pengawet pangan. Boraks atau dikenal sebagai pijer atau bleng yang digunakan sebagai bahan tambahan pada makanan dimana boraks ditambahkan dengan tujuan untuk memberikan struktur padat, meningkatkan kekenyalan, kerenyahan, dan memberikan tekstur padat, serta bersifat tahan lama (Aseptianova et al., 2017).

Dampak buruk, mengkonsumsi makanan yang mengandung boraks tidak dirasakan secara langsung, akan tetapi secara jangka panjang karena senyawa ini akan diserap sedikit demi sedikit dalam tubuh konsumen secara komulatif (Santi, 2017). Menurut Peraturan Menteri Kesehatan RI No. 329/Menkes/PER/XII/1976 disebutkan bahwa yang dimaksud dengan bahan tambahan pangan adalah bahan yang ditambahkan dan dicampurkan sewaktu pengolahan makanan untuk meningkatkan mutu. Dengan adanya peraturan tersebut, yang dimana boraks merupakan bukan bahan tambahan pangan yang tidak diizinkan penggunaannya untuk campuran bahan makanan. Penggunaan bahan kimia seperti boraks untuk makanan ataupun bahan makanan dilakukan agar produk olahan menjadi lebih menarik, lebih tahan lama dan ekonomis, dimana bahaya boraks terhadap kesehatan berdampak negatif karena memiliki efek racun yang dapat membahayakan sistem metabolisme kesehatan seperti iritasi saluran pernafasan, kulit, mata, ginjal, jantung, dan sistem reproduksi.

Sampel yang digunakan berasal dari tiga pasar yang ada di kota Makassar yaitu Pasar Daya (A), Pasar BTP (B), dan (C) Pasar Terong. Pengujian yang dilakukan dengan menganalisis boraks pada kulit pangsit secara kualitatif menggunakan metode uji nyala api dan dengan uji warna kunyit dengan pembuatan paper test kit sederhana.

Pengujian yang pertama dilakukan dengan menggunakan metode uji nyala api dengan memotong kecil-kecil kulit pangsit sebanyak 10 gram, kemudian dipanaskan pada oven untuk mengurangi kadar air kemudian di tambahkan pereaksi asam sulfat sebanyak 2-3 tetes agar 
memberi suasana asam pada sampel yang telah menjadi arang dan metanol sebanyak 5-6 tetes kemudian dilakukan pengujian boraks dengan cara dibakar. Uji boraks pada kulit pangsit dengan menggunakan metode uji nyala api pada sampel A, sampel B, dan Sampel C, menunjukkan hasil tidak mengandung boraks dimana nyala api yang ditimbulkan berwarna merah, jika nyala api berwarna hijau maka sampel positif mengandung boraks, dimana adanya asam borat dalam suatu sampel jika direaksikan dengan $\mathrm{H}_{2} \mathrm{SO}_{4}$ pekat dan metanol pada sampel yang telah disentrifugasi akan menghasilkan nyala berwarna hijau apabila dibakar.

Pengujian yang kedua dilakukan dengan menggunakan uji warna kunyit dengan pembuatan paper test kit sederhana dimana paper test kit ini mampu mendeteksi kandungan boraks pada makanan dengan kadar minimal 200 ppm, semakin besar kadar ppm dari boraks maka semakin jelas warna coklat pada paper test kit. Kemudian pengujian dilakukan dengan membuat ekstrak dari kulit pangsit kemudian di teteskan ke paper test kit.
Analisis boraks pada kulit pangsit dengan menggunakan uji warna kunyit dengan pembuatan paper test kit sederhana pada sampel A, sampel B, dan $\mathrm{C}$, menunjukkan bahwa semua sampel penelitian tidak mengandung boraks dimana pada paper test kit tidak berubah warna. Semakin banyak boraks yang dipakai maka reaksi tersebut warnanya akan semakin gelap pekat (orange-merah-coklat).

\section{Kesimpulan}

Berdasarkan dari hasil penelitian, dapat disimpulkan sampel kulit pangsit dari ketiga pasar di Kota Makassar tidak mengandung boraks sehingga kualitas produk yakni kulit pangsit aman untuk dikonsumsi oleh masyarakat.

\section{Saran}

Untuk peneliti selanjutnya disarankan agar dapat meneliti tentang uji kuantitatif kandungan boraks pada sampel, sehingga dapat diketahui besarnya kadar boraks jika sampel positif secara kualitatif.

\section{DAFTAR PUSTAKA}

Anugrahati Arum Nuri, Natania, Andrew. 2017. Karateristik Sensori Dan Fisik Kulit Pamgsit Goreng Dengan Substitusi Tepung Yang Berbeda Pada Penyimpanan Dingin Dan Beku. Jurnal Agroteknologi, Vol. 11 No. 02: Hal 156,157.

Aseptianova, Dini Afriansyah, Meli Astriani. 2017. Penyuluhan Bahan Makanan Yang Mengandung Boraks di Kelurahan Kebun Bunga Kota Palembang. Jurnal Pengabdian Pada Masyarakat, Volume 2 Nomor 1: Hal 57,58.

Cahyadi Wisnu. 2009. Analisis \& Aspek Kesehatan Bahan Tambahan Pangan Edisi Kedua. Bumi Aksara. Yogyakarta: Hal 5,6,11.

Dolot Fitriani, Fatmawali, Nancy Pelealu. 2016. Analisi Boraks Pada Nugget Olahan Yang DiProduksi Di Kota Kotamobagu. Jurnal of Pharmacy, Vol. 5 No. 4: Hal 214,215.

Fauziyah, Afifah Nur Anna Choirol. 2014. Pengaruh Substansi Mocaf (Modified Cassava Flour) Dan Penambahan Puree Bayam (Amarantus Spp) Pada Hasil Jadi kulit Pangsit. Jurnal Of Boga, Vol 3 No 2: Hal 17.

Falahuddin Irham, Elfira Rosa Pane, Niar Kurniati. 2016. Uji Kandungan Boraks Pada Pempek Lenjer Yang Di Jual Di Kelurahan Pahlawan. Jurnal Biota Vol. 2 No. 2: Hal 143,144.

Helmawati Triana. 2015. Lezat Sih Tapi Sehat Ngaak Ya. Perpustakaan Nasional RI. Yogyakarta: Hal 37.

Kristianto Yohanes. 2010. Panduan Memilih \& Membeli Makanan Sehat. Resist Book. Yogyakarta: Hal 22.

Muharrami Khamsatul Laila. 2015. Analisis Kualitatif Kandungan Boraks Pada Krupuk Puli Di Kecamatan Kamal. Jurnal Pena Sains Vol.2 No.2: Hal 124.

Misba Rachmi Sitti, Satya Darmayani, Narti Nasir. 2017. Analisi Kandungan Boraks Pada Bakso Yang Dijual Di Anduonohu Kota Kendari Sulawesi Tenggara. Jurnal Analisis Kesehatan Vol. 3, No 2: Hal 81.

Santi Parta Utami Apri. 2017. Analisis Kandungan Zat Pengawet Boraks Pada Jajanan Sekolah Di SDN Serua Indah 1 Kota Ciputat. Jurnal Ilmiah PGSD: Hal 58,59,60. 